\title{
Effect of Dates of Sowing and Nitrogen Levels on Growth and Yield of Indian Mustard
}

\author{
Keerthi Pattam*, R.K. Pannu, A.K. Dhaka and K.D. Sharma \\ Department of Agronomy, CCS Haryana Agricultural University Hisar- 125 004, Haryana, India \\ *Corresponding author
}

A B S T R A C T

\begin{tabular}{|c|}
\hline Keywords \\
\hline $\begin{array}{l}\text { Date of sowing, } \\
\text { Nitrogen doses, } \\
\text { Growth, Yield, } \\
\text { Indian mustard. }\end{array}$ \\
\hline Article Info \\
\hline $\begin{array}{l}\text { Accepted: } \\
\text { 17 July } 2017 \\
\text { Available Online: } \\
\text { 10 September } 2017\end{array}$ \\
\hline
\end{tabular}

A field experiment was conducted at CCS Haryana Agricultural University, Hisar to study the effect of date of sowing and nitrogen levels on growth and yield of Indian mustard during 2013-14 and 2014-15. The experiment consisted of 4 dates of sowing and (October 15 , October 25, November 5 and November 15) in main plots and five nitrogen levels $(0$, $40,60,80$ and $100 \mathrm{~kg} \mathrm{~N} / \mathrm{ha}$ ) in sub plots was laid out in split plot design with three replications. Plant height and dry matter accumulation decreased significantly with successive delay in sowing. The increase in nitrogen dose increased the plant height and dry matter accumulation upto $100 \mathrm{~kg} \mathrm{~N} / \mathrm{ha}$ at 120 days after sowing (DAS) and at maturity. Similarly, increase in dose of nitrogen increased the seed yield and biological yield significantly upto $100 \mathrm{~kg} \mathrm{~N} / \mathrm{ha}$ during both the years. However, the biological yield of Indian mustard was statistically at par with highest dose of $100 \mathrm{~kg} \mathrm{~N} / \mathrm{ha}$ with $80 \mathrm{~kg} \mathrm{~N} / \mathrm{ha}$. The growth parameters namely plant height and dry weight have significant positive relationship with seed yield during both the years.

\section{Introduction}

Rapeseed-mustard contributed $20-22 \%$ in total oilseed production in the country, whereas Haryana alone contributed $10.2 \%$ of total rapeseed-mustard production (Anonymous, 2014). In India it is cultivated on 6.70 million hectares with production of $7.96 \mathrm{mt}$ and productivity of $1188 \mathrm{~kg} / \mathrm{ha}$ in 2013-14. Haryana is one of the major rapeseed and mustard growing state and crop occupied 5.4 lakh ha of area producing 8.8 lakh tonnes giving an average yield of 1639 $\mathrm{kg}$ /ha during 2013-14 (Anonymous, 2014). As sowing time is one of the most important nonmonetary input affecting crop yield and other agronomic traits among them, optimization of sowing time for mustard is essential.
Sowing either too early or too late has been reported unfavorable (Hocking and Stapper, 2001). The optimum time of sowing can provide congenial conditions to have maximum light interception, best utilization of moisture and nutrients from early growth stage to seed filling stage. Indian mustard is much sensitive to climatic variables, and climate change has significant effect on its production as well as productivity. One month delay in sowing from mid-October resulted in loss of $40.6 \%$ in seed yield (Lallu et al., 2010). It suffers from exposure to low temperature during vegetative and early pod filling stage and relatively higher temperature during germination and maturity (Aggarwal et 
al., 2004). Plant nutrition is a key input to increase the productivity of mustard seed crop. Nitrogen is considered to be the most important nutrient for the crop to activate the metabolic activity and transformation of energy, chlorophyll and protein synthesis. Nitrogen also affects uptake of other essential nutrients and it helps in the better partitioning of photosynthates to reproductive parts which increase the seed:stover ratio (Singh and Meena, 2004). There is an ample scope for increasing the yield of Indian mustard through fertilizer use, especially nitrogen (Tandon, 1989). The potential yield of Indian mustard can only be harvested by timely sowing and application of nitrogen for different dates of sowing.

\section{Materials and Methods}

The experiment was conducted at the Agronomy Research farm of Chaudhary Charan Singh Haryana Agricultural University, Hisar (India). Hisar is located in Indogangetic plains of North-West India at 215.2 meters above mean sea level with a latitude of $29^{0} 10^{\prime}$ North and longitude of $75^{\circ}$ 36 ' East. The soil of the field was sandy loam, having $0.57 \%$ organic carbon and $\mathrm{pH} 8.73$. It was low in available $\mathrm{N}(155 \mathrm{~kg} / \mathrm{ha})$, medium in available $\mathrm{P}_{2} \mathrm{O}_{5}(23.2 \mathrm{~kg} / \mathrm{ha})$ and rich in available $\mathrm{K}_{2} \mathrm{O}$ (395.6 kg/ha). The experiment consisting of four dates of sowing viz. October 15, October 25, November 5 and November 15 in main plots and five nitrogen levels viz. $0 \mathrm{~kg} \mathrm{~N} / \mathrm{ha}$ (Control), $40 \mathrm{~kg} \mathrm{~N} / \mathrm{ha}, 60$ $\mathrm{kg} \mathrm{N} / \mathrm{ha}, 80 \mathrm{~kg} \mathrm{~N} / \mathrm{ha}$ and $100 \mathrm{~kg} \mathrm{~N} / \mathrm{ha}$ ) in sub plots was laid out in split plot design with three replications. The doses of nitrogen were applied in the form of urea. Half dose of the recommended nitrogen was applied as basal dose and remaining half as top dressing after 1st irrigation during both the seasons. Indian mustard cv. RH 0749 was sown with the help of seed drill in rows $30 \mathrm{~cm}$ apart at a rate of 5 $\mathrm{kg} \mathrm{N} / \mathrm{ha}$. Crop was sown as per treatments. The weeds were removed by long tine hoe at
30 and 60 days after sowing (DAS). The growth parameters were recorded at 30 days interval till crop maturity. The yield was recorded at maturity of the crop.

\section{Results and Discussion}

The perusal of data in table 1 shows that plant height increased with advancement of crop season during both the years. The plant height decreased with delay in sowing date during both the years at all the growth stages significantly. Earlier sown crop (October 15 and 25) faced favourable soil moisture condition and relatively warmer temperature during vegetative phase and conducive temperature during $50 \%$ flowering and pod formation stage, while later sown crop (November 5 and 15) faced low temperature at the time of emergence as well as at $50 \%$ flowering stage. The early sown crop (October 15 and 25) might have maintained better plant relations like leaf water potential (LWP) and higher turgor potential which leads to higher rate of photosynthesis due to more opening of stomata for longer period of time. This has also increased for faster cell division and enlargement, which leads to higher growth rate. Similar findings were recorded by Kumar et al., (2013), Robertson et al., (2004) and Uzun et al., (2009).

The plant height increased with increase in nitrogen dose from 0 to $100 \mathrm{~kg} \mathrm{~N} / \mathrm{ha}$ at all the growth stages. But at $40 \mathrm{~kg} \mathrm{~N} / \mathrm{ha}$, the increase in plant height was significantly higher than control (0 kg N/ha) at 30 DAS during both the years. At 60 DAS, during 2013-14, 120 DAS during 2014-15, and at maturity during both the years, the plant height significantly differed. The minimum plant height was recorded in control $(0 \mathrm{~kg} \mathrm{~N} / \mathrm{ha})$ and maximum plant height in $100 \mathrm{~kg} \mathrm{~N} / \mathrm{ha}$. However, at 60 DAS (2014-15), 120 DAS (2013-14) and 90 DAS during both the years, the difference in plant height at $100 \mathrm{~kg} \mathrm{~N} / \mathrm{ha}$ was statistically on par with $80 \mathrm{~kg} \mathrm{~N} / \mathrm{ha}$. The plant height 
increased with the increased doses of nitrogen but the variation in plant height with subsequent increase in dose have slight increase in the plant height. This may be because of plant height being the genetic character, hence affected less by environment, but the plant height in control i.e. $0 \mathrm{~kg} \mathrm{~N} / \mathrm{ha}$ was reduced significantly than the other doses of nitrogen might be because of under nourishment of the plant because of low availability of nutrients as no nitrogen was applied in this treatment.

The data pertaining to dry matter accumulation are presented in table 2 . The dry matter accumulation increased with advancement in crop age during both the years of experimentation. The dry matter accumulation decreased significantly with delay in sowing during both the years at all the growth stages i.e., 30, 90, 120 and at maturity. However, the difference in dry matter accumulation at 60 DAS between October 25 and November 5 was statistically on par with each other during 2013-14. But the dry matter accumulation was significantly decreased with delay in sowing at 60 DAS during 2014-15. The dry weight accumulation (Table 2) was significantly higher under first date of sowing during both the seasons at maturity because of early sown crop (October 15 and 25) faced favourable soil moisture condition and relatively warmer temperature during vegetative phase and conducive temperature during $50 \%$ flowering and pod formation stage, while later sown crop (November 5 and 15) faced low temperature at the time of emergence as well as at 50\% flowering stage. The early sown crop (October 15 and 25) might have maintained better plant relations like leaf water potential (LWP) and higher turgor potential which leads to higher rate of photosynthesis due to more opening of stomata for longer period of time. The increase in nitrogen dose increased the dry matter accumulation significantly up to $100 \mathrm{~kg} \mathrm{~N} / \mathrm{ha}$ at maturity, $120 \mathrm{DAS}$ and at
30 DAS during 2014-15. However the difference in dry matter accumulation at $80 \mathrm{~kg}$ $\mathrm{N} / \mathrm{ha}$ was statistically at par with $60 \mathrm{~kg} \mathrm{~N} / \mathrm{ha}$ and $100 \mathrm{~kg} \mathrm{~N} / \mathrm{ha}$ at $60 \mathrm{DAS}$ during 2014-15 and 120 DAS during 2013-14. At 60 DAS during 2013-14 and at 90 DAS during both the years, the difference in dry matter accumulation between 80 and $100 \mathrm{~kg} \mathrm{~N} / \mathrm{ha}$ were statistically not differed. The dry weight was significantly lower in control than higher doses of nitrogen. Poor growth in these treatments may be due to low availability of plant nutrient which are necessary for the normal growth. Nitrogen being the basic constituent of chlorophyll, protein and cellulose required for the process of photosynthesis and tissue formation for proper growth. The growth at higher level of nitrogen application i.e. $100 \mathrm{~kg} \mathrm{~N} / \mathrm{ha}$ were increased significantly and it was at par with recommended dose of nitrogen. These results collaborate with the findings of Maereka $e t$ al., (2007)

\section{Yield and harvest index}

The results pertaining to seed yield, biological yield and harvest index in relation to dates of sowing and nitrogen levels are presented in table 3. The difference in seed yield among the dates of sowing was obtained to be significant. The maximum seed yield of 2683 and $2586 \mathrm{~kg} / \mathrm{ha}$ was obtained with crop sown on October $15^{\text {th }}$ which was statistically on par with crop sown on October $25^{\text {th }}$ (2498 and $2392 \mathrm{~kg} / \mathrm{ha}$ ), thereafter seed yield decreased with delay in sowing during 2013-14 and 2014-15, respectively. Minimum seed yield was obtained with November $15^{\text {th }}$ sown crop (1614 and1585 kg/ha), which was significantly lower than November $5^{\text {th }}$, October $25^{\text {th }}$ and October $15^{\text {th }}$ sown crop during first and second year, respectively. Early (October 15 and 25) sown crop received the optimum environment conditions required for better crop growth in terms of plant height, and dry matter accumulation. 
Table.1 Effect of sowing time and nitrogen levels on plant height $(\mathrm{cm})$ of Indian mustard at different growth stages

\begin{tabular}{|c|c|c|c|c|c|c|c|c|c|c|}
\hline \multirow[t]{3}{*}{ Treatments } & \multicolumn{10}{|c|}{ Days after sowing } \\
\hline & \multicolumn{2}{|c|}{30} & \multicolumn{2}{|c|}{60} & \multicolumn{2}{|c|}{90} & \multicolumn{2}{|c|}{120} & \multicolumn{2}{|c|}{ At maturity } \\
\hline & 2013-14 & 2014-15 & 2013-14 & 2014-2015 & 2013-14 & 2014-15 & 2013-14 & 2014-15 & 2013-14 & 2014-15 \\
\hline \multicolumn{11}{|l|}{ Time of sowing } \\
\hline Oct 15 & 29.9 & 28.0 & 125.8 & 121.3 & 210.5 & 208.1 & 226.4 & 224.2 & 227.6 & 225.7 \\
\hline Oct 25 & 23.7 & 22.9 & 119.3 & 117.3 & 209.9 & 205.0 & 223.2 & 218.8 & 224.2 & 220.4 \\
\hline Nov 5 & 21.9 & 20.7 & 115.2 & 113.0 & 207.1 & 204.6 & 218.9 & 214.7 & 220.2 & 216.3 \\
\hline Nov 15 & 18.7 & 18.5 & 109.8 & 107.5 & 199.4 & 197.8 & 209.0 & 206.4 & 209.1 & 207.9 \\
\hline $\mathrm{CD}(\mathrm{P}=0.05)$ & 4.5 & 4.1 & 3.8 & 1.2 & 7.3 & 3.7 & 3.8 & 1.9 & 2.1 & 1.9 \\
\hline \multicolumn{11}{|c|}{ Nitrogen levels (kg/ha) } \\
\hline 0 kg N/ha & 21.6 & 20.7 & 109.3 & 106.6 & 201.1 & 198.7 & 212.5 & 208.4 & 212.7 & 209.9 \\
\hline $40 \mathrm{~kg} \mathrm{~N} / \mathrm{ha}$ & 23.0 & 21.8 & 112.0 & 108.6 & 204.0 & 199.5 & 214.0 & 209.7 & 214.2 & 211.2 \\
\hline $60 \mathrm{~kg} \mathrm{~N} / \mathrm{ha}$ & 23.9 & 22.7 & 116.7 & 114.3 & 207.1 & 204.0 & 221.0 & 217.1 & 221.0 & 218.7 \\
\hline $80 \mathrm{~kg}$ N/ha & 24.8 & 23.7 & 122.9 & 121.4 & 210.4 & 208.2 & 224.4 & 220.9 & 225.8 & 222.4 \\
\hline $100 \mathrm{~kg} \mathrm{~N} / \mathrm{ha}$ & 24.8 & 23.7 & 126.7 & 123.5 & 210.5 & 208.9 & 225.1 & 224.0 & 227.7 & 225.6 \\
\hline $\mathrm{CD}(\mathrm{P}=0.05)$ & 1.1 & 1.0 & 2.3 & 2.3 & 3.3 & 2.3 & 3.0 & 2.5 & 1.9 & 2.5 \\
\hline
\end{tabular}

Table.2 Effect of sowing time and nitrogen levels on dry weight $(\mathrm{g})$ per plant of Indian mustard at different growth stages

\begin{tabular}{|c|c|c|c|c|c|c|c|c|c|c|}
\hline \multirow[t]{3}{*}{ Treatments } & \multicolumn{10}{|c|}{ Days after sowing } \\
\hline & \multicolumn{2}{|c|}{30} & \multicolumn{2}{|c|}{60} & \multicolumn{2}{|c|}{90} & \multicolumn{2}{|c|}{120} & \multicolumn{2}{|c|}{ At maturity } \\
\hline & 2013-14 & 2014-15 & 2013-14 & 2014-2015 & 2013-14 & 2014-15 & 2013-14 & 2014-15 & 2013-14 & 2014-15 \\
\hline \multicolumn{11}{|l|}{ Time of sowing } \\
\hline Oct 15 & 1.25 & 1.04 & 8.20 & 7.93 & 52.14 & 50.6 & 135.4 & 130.3 & 148.9 & 141.1 \\
\hline Oct 25 & 1.11 & 0.89 & 7.63 & 7.29 & 45.73 & 45.2 & 126.4 & 122.0 & 133.9 & 128.5 \\
\hline Nov 5 & 0.98 & 0.77 & 7.44 & 7.07 & 40.68 & 36.5 & 121.9 & 113.2 & 126.7 & 118.6 \\
\hline Nov 15 & 0.83 & 0.63 & 6.89 & 6.26 & 36.02 & 34.3 & 108.3 & 106.0 & 112.3 & 111.0 \\
\hline $\mathrm{CD}(\mathrm{P}=0.05)$ & 0.11 & 0.04 & 0.28 & 0.17 & 1.57 & 1.5 & 1.9 & 0.6 & 2.2 & 1.4 \\
\hline \multicolumn{11}{|c|}{ Nitrogen levels (kg/ha) } \\
\hline $0 \mathrm{~kg} \mathrm{~N} / \mathrm{ha}$ & 0.81 & 0.63 & 6.18 & 5.52 & 34.8 & 34.0 & 115.3 & 108.3 & 115.3 & 113.9 \\
\hline $40 \mathrm{~kg} \mathrm{~N} / \mathrm{ha}$ & 0.97 & 0.76 & 7.26 & 7.01 & 43.4 & 40.4 & 120.9 & 114.8 & 125.7 & 120.7 \\
\hline $60 \mathrm{~kg} \mathrm{~N} / \mathrm{ha}$ & 1.03 & 0.83 & 7.80 & 7.52 & 44.4 & 43.2 & 124.9 & 119.8 & 132.5 & 126.6 \\
\hline $80 \mathrm{~kg} \mathrm{~N} / \mathrm{ha}$ & 1.16 & 0.93 & 8.15 & 7.72 & 47.5 & 45.0 & 125.9 & 121.7 & 137.2 & 129.1 \\
\hline $100 \mathrm{~kg} \mathrm{~N} / \mathrm{ha}$ & 1.25 & 1.00 & 8.31 & 7.93 & 47.9 & 45.7 & 128.1 & 124.8 & 142.2 & 133.6 \\
\hline $\mathrm{CD}(\mathrm{P}=\mathbf{0 . 0 5})$ & 0.04 & $\mathbf{0 . 0 3}$ & 0.18 & 0.30 & 0.75 & 1.0 & 2.21 & 1.6 & 2.0 & 1.3 \\
\hline
\end{tabular}


Table.3 Effect of sowing time and nitrogen levels on yield of Indian mustard

\begin{tabular}{|c|c|c|c|c|c|c|c|c|c|}
\hline \multirow{2}{*}{ Treatments } & \multicolumn{2}{|c|}{ Seed yield $(\mathrm{kg} / \mathrm{ha})$} & \multirow{2}{*}{ POOLED } & \multicolumn{2}{|c|}{ Stover yield (kg/ha) } & \multicolumn{2}{|c|}{ Biological yield (kg/ha) } & \multicolumn{2}{|c|}{ Harvest index (\%) } \\
\hline & 2013-14 & 2014-15 & & 2013-14 & 2014-15 & 2013-14 & 2014-15 & 2013-14 & 2014-15 \\
\hline \multicolumn{10}{|l|}{ Time of sowing } \\
\hline Oct 15 & 2683 & 2586 & 2635 & 9336 & 9049 & 12020 & 11636 & 22.0 & 21.8 \\
\hline Oct 25 & 2498 & 2392 & 2445 & 8734 & 8471 & 11232 & 10864 & 21.9 & 21.6 \\
\hline Nov 5 & 2033 & 1951 & 1992 & 7470 & 7167 & 9503 & 9119 & 19.3 & 21.2 \\
\hline Nov 15 & 1614 & 1585 & 1599 & 6184 & 5829 & 7797 & 7414 & 18.2 & 21.0 \\
\hline $\mathrm{CD}(\mathrm{P}=\mathbf{0 . 0 5})$ & 214 & 208 & 211 & 791 & 642 & 741 & 579 & 2.6 & NS \\
\hline \multicolumn{10}{|c|}{ Nitrogen levels (kg/ha) } \\
\hline 0 kg N/ha & 1277 & 1182 & 1229 & 6728 & 6459 & 8005 & 7641 & 15.4 & 15.1 \\
\hline $40 \mathrm{~kg} \mathrm{~N} / \mathrm{ha}$ & 2069 & 1987 & 2028 & 7304 & 7002 & 9373 & 8989 & 22.1 & 21.0 \\
\hline $60 \mathrm{~kg} \mathrm{~N} / \mathrm{ha}$ & 2410 & 2344 & 2377 & 8185 & 7867 & 10595 & 10212 & 22.9 & 21.6 \\
\hline $80 \mathrm{~kg} \mathrm{~N} / \mathrm{ha}$ & 2597 & 2523 & 2560 & 8620 & 8310 & 11217 & 10833 & 23.3 & 22.0 \\
\hline $100 \mathrm{~kg} \mathrm{~N} / \mathrm{ha}$ & 2681 & 2608 & 2644 & 8818 & 8507 & 11500 & 11116 & 23.5 & 22.1 \\
\hline $\mathrm{CD}(\mathrm{P}=0.05)$ & 68.5 & 67.4 & 67.0 & 432 & 435 & 446 & 445 & 1.1 & 0.9 \\
\hline
\end{tabular}


Fig.1 Regression line showing the relationship of biological yield ( $\mathrm{kg} / \mathrm{ha}$ ) with seed yield $(\mathrm{kg} / \mathrm{ha})$

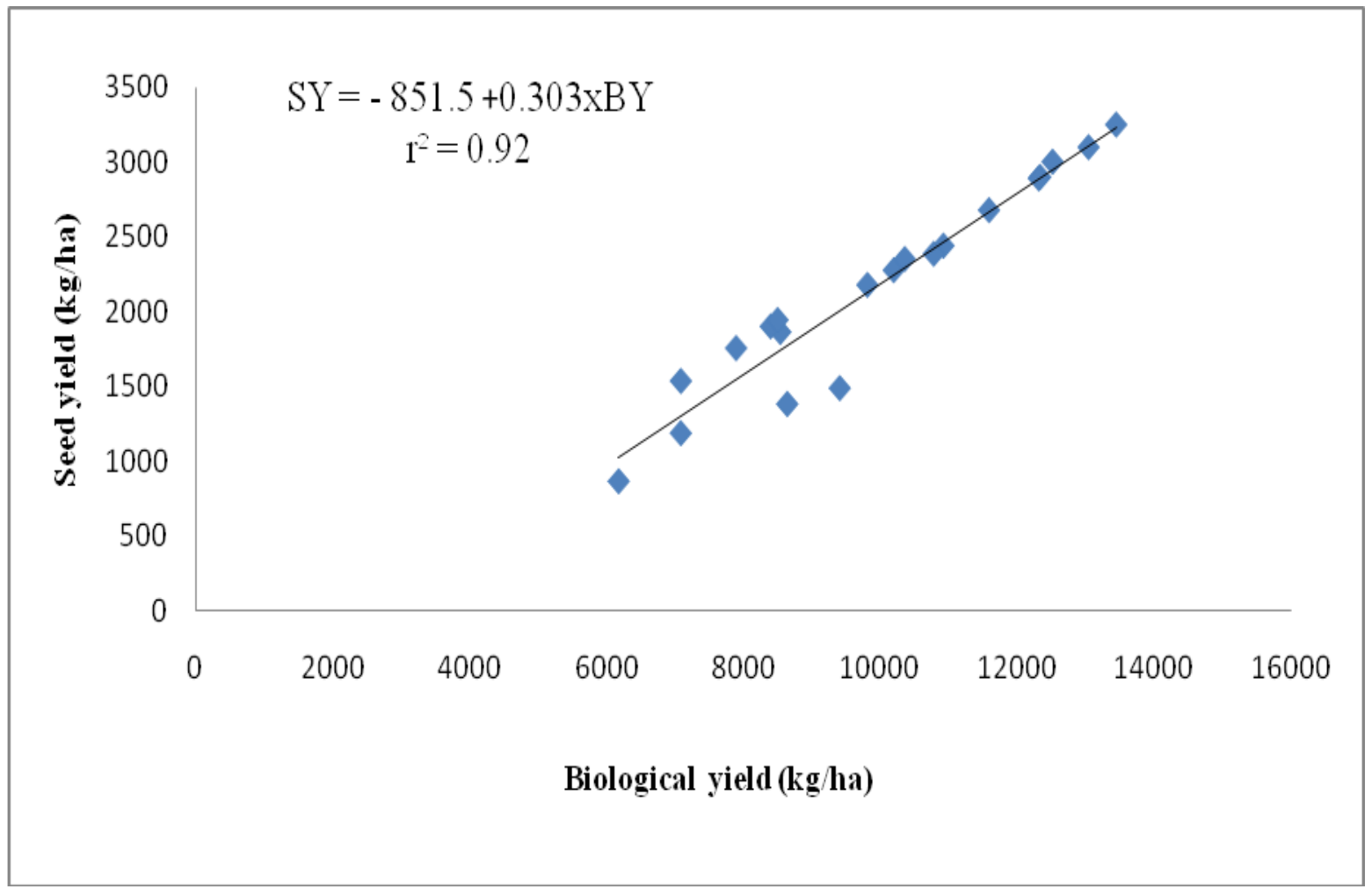

Fig.2 Regression line showing the relationship of harvest index (\%) with seed yield $(\mathrm{kg} / \mathrm{ha})$

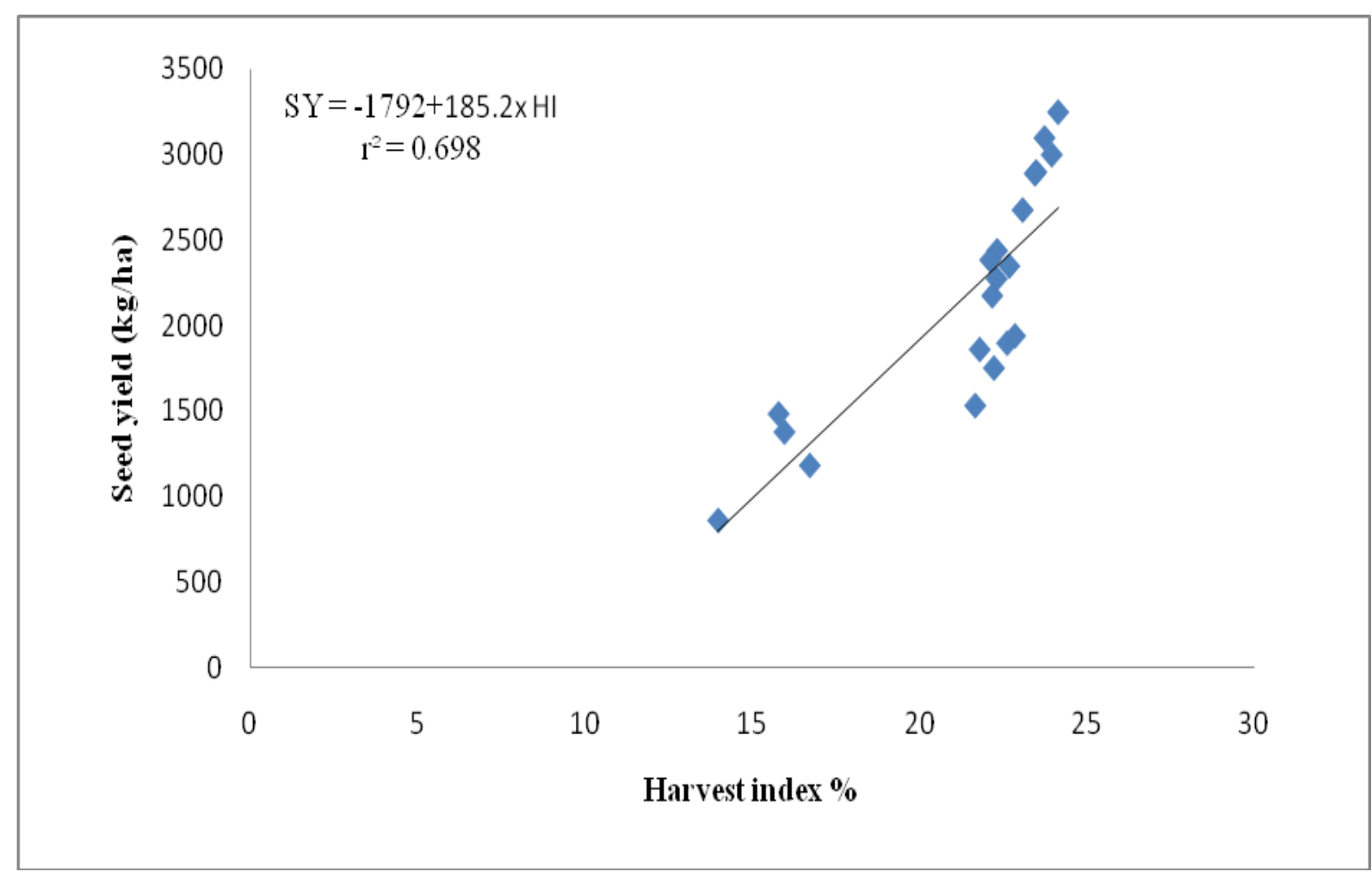


The significantly positive association between biological yield with growth parameters namely plant height $(\mathrm{r}=0.95)$ and dry weight $(\mathrm{r}=0.96)$.

The effect of nitrogen doses on seed yield of mustard are shown in table 3. The mustard yield increased significantly with increased dose of nitrogen. The minimum seed yield was found in control i.e. $0 \mathrm{~kg}$ N/ha $1277 \mathrm{~kg} / \mathrm{ha}$ in 2013-14 and $1182 \mathrm{~kg} / \mathrm{ha}$ in $2014-15$ and increase in yield was significant up to $100 \mathrm{~kg} \mathrm{~N} / \mathrm{ha}$. Maximum seed yield $2681 \mathrm{~kg} / \mathrm{ha}$ in 2013-14 and 2608 $\mathrm{kg} / \mathrm{ha}$ in 2014-15 was recorded with $100 \mathrm{~kg}$ $\mathrm{N} /$ ha which was significantly higher than 80 , 60,40 and $0 \mathrm{~kg} \mathrm{~N} / \mathrm{ha}$ during both the years of experimentation.

The response of biological yield of mustard to different dates of sowing was obtained to be significant. The maximum biomass production $(12020 \mathrm{~kg} / \mathrm{ha}$ in $2013-14$ and $11232 \mathrm{~kg} / \mathrm{ha}$ in 2014-15) was obtained when crop sown on October 15 which was significantly higher when compared to crop sown on October 25 (11232 $\mathrm{kg} / \mathrm{ha}$ in $2013-14$ and $10864 \mathrm{~kg} / \mathrm{ha}$ in $2014-15$ ) November 5 (9503 kg/ha in 2013-14 and 9119 $\mathrm{kg} / \mathrm{ha}$ in 2014-15) and November 15 (7797 $\mathrm{kg} / \mathrm{ha}$ in 2013-14 and $7414 \mathrm{~kg} / \mathrm{ha}$ in 2014-15). The Indian mustard biological yield increase significantly with dose of nitrogen. The minimum biological yield was found in control i.e. $0 \mathrm{~kg} \mathrm{~N} / \mathrm{ha}(8005 \mathrm{~kg} / \mathrm{ha}$ in $2013-14$ and 7641 $\mathrm{kg} / \mathrm{ha}$ in 2014-15) and the increase in biological yield was significant up to $60 \mathrm{~kg} \mathrm{~N} / \mathrm{ha}$ during both the years of study. However, the biological yield at $80 \mathrm{~kg} \mathrm{~N} / \mathrm{ha}(11217 \mathrm{~kg} / \mathrm{ha}$ in $2013-14$ and $10833 \mathrm{~kg} / \mathrm{ha}$ in $2014-15)$ was statistically at par with $100 \mathrm{~kg} \mathrm{~N} / \mathrm{ha}(11500 \mathrm{~kg} / \mathrm{ha}$ in $2013-14$ and $11116 \mathrm{~kg} / \mathrm{ha}$ in 2014-15) during both the years of experimentation. The stronger source is required for the stronger sink. The higher biological yield was found significantly associated with higher seed yield of mustard $(r=0.96)$. This clearly shows the biological yield increased by any input or management practice will automatically increase the seed yield of mustard. The seed yield of mustard can also be estimated through biological yield with the regression equation (Fig 1 . Seed yield = -
$851.5+0.303$ biological yield, $\mathrm{r}^{2}=0.92$ ). Similar results have been reported by Singh et al., (2014) and Keivanrad et al., (2012).

The data pertaining in table 3 indicates that harvest index (HI) of Indian mustard was influenced significantly by the different dates of sowing during 2013-14. The maximum harvest index was observed in October 15 sown crop (22.0), followed by October 25 sown crop (21.9), followed by crop sown at November 5(19.3). The minimum harvest index was obtained (18.2) when crop sown on November 15. However, the harvest index of Indian mustard during 2014-15 was not influenced by dates of sowing. The Indian mustard harvest index increased significantly with increased dose of nitrogen. The increase in harvest index was significant up to $40 \mathrm{~kg} \mathrm{~N} / \mathrm{ha}$ during both the years of study. However, the H.I of 60 (22.9 and 21.6), 80 (23.3 and 22.0) and $100 \mathrm{~kg} \mathrm{~N} / \mathrm{ha}$ (23.5 and 22.1) was statistically at par during both the years of experimentation. Seed yield increased significantly with increase in nitrogen doses up to to $100 \mathrm{~kg} \mathrm{~N} / \mathrm{ha}$ (Table 3). The significantly higher seed yield (109 and $120 \%$ ), stover yield (31.1 and $31.7 \%$ ) and biological yield (43.7 and $45.4 \%$ ) along with the harvest index (52.6 and $46.3 \%$ ) in $100 \mathrm{~kg} \mathrm{~N} / \mathrm{ha}$ over control were because of more availability of nutrients for their growth and development of better yield attributes and yield. The poor nutrition in control affected the seed yield more than biological yield which ultimately resulted in significant reduction in harvest index. Harvest index is the parameter which dependent on seed yield $(r=0.83)$ and biological yield $(\mathrm{r}=0.66)$. This shows that harvest index was more associated with seed yield than biological yield. The harvest index can also be computed from the seed yield with regression equation $\left(\mathrm{SY}=-1792+185.2 \mathrm{HI}, \mathrm{r}^{2}=0.70\right.$, Fig. 2). This decline in response of nitrogen at higher doses may be explained with the well-established Mitscharlich equation. Similar trend have been reported by Keivendra et al., (2012) Reager et al., (2006) Premi and Kumar (2004). 


\section{References}

Aggarwal, P.K., Kalra, N., Chander, S. and Pathak, H. 2004. Info Crop: A generic simulation model for annual crops in tropical environments. Indian Agricultural research Institutes, New Delhi, and P.132.

Anonmyous, 2014.www.Indiastat.com.

Hocking, P.J. and Stapper, M. 2001. Effects of sowing time and nitrogen fertilizer on canola and wheat, and nitrogen fertilizer on Indian mustard. I. Dry matter production, grain yield, and yield components. Australian Journal of Agricultural Research, 52(6): 623-634.

Keivanrad, S., Delkosh, B., Hossein, A., Shirani, R. and Zandi, P. 2012. The Effect of different rates of nitrogen and plant density on qualitative and quantitative traits of Indian mustard. Advances in Environmental Biology, 6 (1): 145-152.

Kumar, S., Sairam, R. K. and Prabhu, K.V. 2013. Physiological traits for high temperature stress tolerance in Brassica Juncea. Indian Journal of Plant Physiology, 18 (1): 89-93.

Lallu, R.S., Baghel, V.S. and Srivastava, S.B.L. 2010. Assessment of mustard genotypes for thermo tolerance at seed development stage. Indian Journal of Plant Physiology, 15(1): 36-43.

Maereka, E.K., Madakadze, R.M., Mashingaidze, A.B. Kageler and Nyakanda, C. 2007. Effect of nitrogen fertilization and timing of harvesting on leaf nitrate content and taste in mustard rape (Brassica juncea L. Czern). Journal of Food, Agriculture and Environment, 5(3\&4): 288-293.

Premi, O.P., and Kumar, M. 2004. Response of Indian mustard (Brassica juncea) to different levels of nitrogen and phosphorous under irrigated condition. Indian Journal of Agricultural Research 38 (2): 151-153.

Reager, M.L., Sharma, S.K. and Yadav, R.S. 2006. Yield attributes, yield and nutrient uptake of Indian mustard (Brassica juncea) as influenced by nitrogen levels and its split application in arid western Rajasthan. Indian Journal of Agronomy, 51(3): 213-216.

Robertson, M. J., Holland, J. F. and Bambach, R. 2004. Response of canola and Indian mustard to sowing date in the grain belt of north-eastern Australia. Australian Journal of Experimental Agriculture, 44: 43-52.

Singh, A., and Meena, N.L. 2004. Effect of nitrogen and sulphur on growth, yield attributes and seed yield of mustard (Brassica juncea) in eastern plains of Rajasthan. Indian Journal of Agronomy, 49(3): 186-188.

Singh, S., Jha, V.B. Singh, R.N. Akhauri, R.K. and Singh, B. 2014. Effect of cropping system and different levels of nitrogen fertilizer on yield performance of mustard in rainfed situation. Annals of Agri-Bio Research, 19(3): 420-421

Tandon, H.L.S., 1989. Crop responses and economics. (In) Secondary and Micronutrient recommendations for Soils and Crops-A Guide Book, pp. 8-9, 33-43. Fertiliser Development and Consultation Organization. New Delhi.

Uzun, B., Zengin, U., Furat, S. and Akdesir, O. 2009. Sowing date effects on growth, flowering, seed yield and oil content of canola cultivars. Asian Journal of Chemistry, 21: 1957-1965.

\section{How to cite this article:}

Keerthi Pattam, R.K. Pannu, A.K. Dhaka and Sharma, K.D. 2017. Effect of Dates of Sowing and Nitrogen Levels on Growth and Yield of Indian Mustard. Int.J.Curr.Microbiol.App.Sci. 6(9): 10291036. doi: https://doi.org/10.20546/ijcmas.2017.609.124 